\title{
Atmospheric Environment
}

\section{Current ozone levels threaten gross primary production and yield of Mediterranean annual pastures and nitrogen modulates the response}

\author{
Héctor Calvete-Sogo , Susana Elvira , Javier Sanz , Ignacio González-Fernández , \\ Héctor García-Gómez , Laura Sánchez-Martín , Rocío Alonso , \\ Victoria Bermejo-Bermejo
}

\begin{abstract}
A B S T R A C T
Pastures are among the most important ecosystems in Europe considering their biodiversity and distribution area. However, their response to increasing tropospheric ozone $\left(\mathrm{O}_{3}\right)$ and nitrogen $(\mathrm{N})$ deposition, two of the main drivers of global change, is still uncertain. A new Open-Top Chamber (OTC) experiment was performed in central Spain, aiming to study annual pasture response to $\mathrm{O}_{3}$ and $\mathrm{N}$ in close to natural growing conditions. A mixture of six species of three representative families was sowed in the field. Plants were exposed for 40 days to four $\mathrm{O}_{3}$ treatments: filtered air, non-filtered air (NFA) reproducing ambient levels and NFA supplemented with 20 and $40 \mathrm{nl} \mathrm{I}^{-1} \mathrm{O}_{3}$. Three $\mathrm{N}$ treatments were considered to reach the $\mathrm{N}$ integrated doses of "background", +20 or $+40 \mathrm{~kg} \mathrm{~N} \mathrm{ha}^{-1}$. Ozone significantly reduced green and total aboveground biomass (maximum reduction 25\%) and increased the senescent biomass (maximum increase $40 \%$ ). Accordingly, $\mathrm{O}_{3}$ decreased community Gross Primary Production due to both a global reduction of ecosystem $\mathrm{CO}_{2}$ exchange and an increase of ecosystem respiration. Nitrogen could partially counterbalance $\mathrm{O}_{3}$ effects on aboveground biomass when the levels of $\mathrm{O}_{3}$ were moderate, but at the same time $\mathrm{O}_{3}$ exposure reduced the fertilization effect of higher $\mathrm{N}$ availability. Therefore, $\mathrm{O}_{3}$ must be considered as a stress factor for annual pastures in the Mediterranean areas.
\end{abstract}

\section{Introduction}

Tropospheric ozone $\left(\mathrm{O}_{3}\right)$ and atmospheric nitrogen $(\mathrm{N})$ deposition are two of the main air pollutants affecting natural and semi-

* Corresponding author. Ecotoxicology of Air Pollution, CIEMAT (Edif. 70), Avda. Complutense 40, 28040 Madrid, Spain.

E-mail addresses: hector.calvete@ciemat.es (H. Calvete-Sogo), susana.elvira@ ciemat.es (S. Elvira), j.sanz@ciemat.es (J. Sanz), ignacio.gonzalez@ciemat.es (I. González-Fernández), hector.garcia@ciemat.es (H. García-Gómez), laura. sanchez@upm.es (L. Sánchez-Martín), rocio.alonso@ciemat.es (R. Alonso), victoria. bermejo@ciemat.es (V. Bermejo-Bermejo). natural areas and causing harmful ecological effects (EEA, 2011; Sutton et al., 2011). In the Mediterranean area, high solar radiation, temperature and prevailing stable atmospheric conditions favor photochemical $\mathrm{O}_{3}$ formation (Millán et al., 2000; Cristofanelli and Bonasoni, 2009), resulting in some of the highest surface $\mathrm{O}_{3}$ concentrations in Europe (EEA, 2011). Ozone concentrations in Spain frequently exceed current thresholds established for plant protection according to the EU Air Quality Directive 2008/50/EC or the Convention on Long-Range Transboundary Air Pollution of the UN/ECE (CLRTAP) (Fernández-Fernández et al., 2011). Moreover, $\mathrm{O}_{3}$-induced effects have been reported in crops and natural 
vegetation (Ferretti et al., 2007; Bermejo et al,, 2011). Total atmospheric $N$ deposition in Spain reaches values up to 23-30 kg N ha ${ }^{-1}$ year $^{-1}$ (Àvila and Rodà, 2012; García-Gómez et al., 2014). These values are a relatively lower than deposition levels recorded in central Europe. However, since changes in species composition occur early in the sequence of $\mathrm{N}$ saturation (Emmett, 2007), $\mathrm{N}$ deposition effects could be occurring in Spanish natural ecosystems. Unfortunately, despite the presence of extraordinary biological richness in the Mediterranean Basin, very little information is available on the threat that air pollution and in particular reactive $\mathrm{N}$, can pose to biodiversity in this area (Ochoa-Hueso et al., 2011).

Most of the research on ecosystems responses to air pollution has been focused on the effects of a single pollutant while air pollutants seldom occur individually. Interactive effects of $\mathrm{O}_{3}$ and $\mathrm{N}$ deposition are still poorly understood. Higher $\mathrm{N}$ availability can increase plant productivity providing higher resource availability for investing in defense, repair and compensation processes counterbalancing $\mathrm{O}_{3}$ effects, or may exacerbate $\mathrm{O}_{3}$ damage due to stimulated growth and higher specific leaf area (Bytnerowicz, 2002; Ashmore, 2005; Bassin et al., 2007). On the other hand, $\mathrm{O}_{3}$ can inhibit some N-related enzyme activities and reduce the allocation of assimilates to roots and root growth (Bytnerowicz, 2002; Ashmore, 2005), thus diminishing the fertilization effects of higher $\mathrm{N}$ levels.

Grasslands communities represent an important contribution to global biodiversity. Experiments with single species have shown a wide range of $\mathrm{O}_{3}$ sensitivity (Bassin et al., 2007; Hayes et al., 2007). However, the response of plant communities cannot readily be predicted from the response of their component species, and little information is available on the effects of $\mathrm{O}_{3}$ on pasture communities (Bassin et al., 2007; Cape, 2008). Communities of temperate perennial grasslands have shown higher resilience to $\mathrm{O}_{3}$ compared to individual species (Thwaites et al., 2006; Volk et al., 2011). On the other hand, chronic $\mathrm{N}$ deposition is reducing plant species richness of European temperate acid grasslands (Stevens et al., 2004; Dupre et al., 2010). The combination of $\mathrm{O}_{3}$ and $\mathrm{N}$ deposition on perennial grasslands shows contrasting results with no interactive effects or an additive response in $\mathrm{C}$ allocation in some species (Volk et al., 2011; Wyness et al., 2011).

Fewer works have been focused on the response of annual pastures to air pollution. Annual grasslands constitute the understorey of broadleaf evergreen forests, and dehesa traditional agroforestry systems. These ecosystems are protected by the 92/43/ EEC Habitat Directive and included in the Nature 2000 network. Previous experiments with individual species grown in pots showed that $\mathrm{O}_{3}$ induces visible injury, accelerates senescence and reduces biomass production and consumable food value of some representative species (Bermejo et al., 2003; Gimeno et al., 2004a,b; Sanz et al., 2005, 2007, 2011). Interestingly, nitrogen fixing legumes, with high nutritive quality for herbivorous feeding, were $\mathrm{more}_{3}$ sensitive than grasses (Bermejo et al., 2003; Gimeno et al., 2004a). Moreover, $\mathrm{O}_{3}$ strongly reduced flower and seed production of some sensitive legumes (Gimeno et al., 2004b; Sanz et al., 2007) which could interfere with species perpetuation and competitive fitness. For some species, $\mathrm{N}$ fertilization counterbalanced $\mathrm{O}_{3}$ effects on senescence and plant and flower biomass, when plants were exposed to moderate $\mathrm{O}_{3}$ concentrations (Sanz et al., 2005, 2007, 2011). Experiments with annual plant communities are needed to test if results obtained with individual species grown in pots are applicable for $\mathrm{O}_{3}$ risk assessment to annual grassland communities.

An experiment has been carried out to study the interactive effects of $\mathrm{O}_{3}$ and $\mathrm{N}$ fertilization on a simplified annual community. The main hypotheses were that $\mathrm{O}_{3}$ affects community gas exchange rates reducing biomass production, and that $\mathrm{N}$ can modulate the negative response to this pollutant. To our knowledge this is the first experiment providing results of effects of $\mathrm{O}_{3}$ and $\mathrm{N}$ fertilization on an annual grassland community.

\section{Materials and methods}

\subsection{Experimental site}

The experiment was performed in a new Open Top Chamber (OTC) facility located in the Spanish central plateau at Santa Olalla ( 450 m.a.s.l.; $40^{\circ} 3^{\prime} \mathrm{N}, 4^{\circ} 26^{\prime} \mathrm{W}$ ), in the scientific experimental farm "La Higueruela" (CSIC). The area presents a Thermo-Mediterranean temperate climate, with moderate winters and dry summers. The field site is far from local sources of air pollution and at $80 \mathrm{~km}$ downwind of Madrid City. The soil is a calcic luvisol, characterized by differentiation pedogenetic of clay ( $11.4 \%$ clay, $24 \%$ silt, $64.6 \%$ sand). Further information of edaphic and physic-chemical characteristics of Ap horizon is provided in Appendix (Table A.1.)

\subsection{Plant material}

A simplified pasture community was sown on the ground using 6 representative annual species: 3 legumes (Trifolium striatum, Trifolium cherleri, Ornithopus compressus), 2 grasses (Briza maxima, Cynosurus echinatus) and 1 forb (Silene gallica) (Table 1). The family composition followed a proportion of $45 \%$ leguminous, $45 \%$ grasses and $10 \%$ caryophylaceae. Legumes and grasses are the most abundant species in natural annual pastures (Montoya et al., 1988). Species selection was based on natural abundance, relatively homogeneous seed size to allow homogeneous sowing, seed availability, high seed germinative capacity and $\mathrm{O}_{3}$-sensitivity based on previous studies (Bermejo et al., 2003; Gimeno et al., 2004; Sanz et al., 2007). Before the experiment, in order to reduce plants growing from the natural soil seed bank inside the experimental plots, seeds present in the soil were successively allowed to germinate and seedlings were eliminated afterwards turning over $20 \mathrm{~cm}$ of top soil. Experimental seeds were sown on February 11th 2011 , aiming for a density of 1000 plant $\mathrm{m}^{-2}$ using the proportion of species seeds indicated in Table 1; the sowing mixture was adjusted according to seed weight and germination capacity tested previously. The homogeneity of species germination and distribution inside the chambers was tested and confirmed 5 days after emergence (DaE). Every week, alien species were manually removed.

\subsection{Experimental design}

The experiment followed a split-plot design conducted in 15 plots with four $\mathrm{O}_{3}$ treatments three times replicated (i.e. a total of 12 OTCs with 3 OTCs per $\mathrm{O}_{3}$ treatment) and three ambient plots without chamber. Four $\mathrm{O}_{3}$ treatments were considered: charcoal filtered air (FA), non-filtered air (NFA) reproducing ambient levels, non-filtered air supplemented with $20 \mathrm{nl} \mathrm{l}^{-1} \mathrm{O}_{3}(\mathrm{NFA}+$ ) and nonfiltered air supplemented with $40 \mathrm{nl}^{-1} \mathrm{O}_{3}(\mathrm{NFA}++$ ). Ambient air chamberless plots $(\mathrm{AA})$ were considered to evaluate the chamber effect. The experimental unit was the NCLAN-type OTC (adapted from the original OTC design used in the National Crop Loss Assessment Program of the Environmental Protection Agency, USA Heck et al., 1982). Ozone supply for NFA+ and NFA++ treatments was applied during $8 \mathrm{~h} \mathrm{day}^{-1}$ (7:00 to 15:00 GTM) 7 day week $^{-1}$ by mean of an $\mathrm{O}_{3}$ generator (Model 16, A2Z Ozone Systems Inc., USA) system fed with pure oxygen. Ozone ( $\mathrm{ML}^{\circledR} 9810 \mathrm{~B}$, Teledyne, USA), sulfur dioxide $\left(\mathrm{SO}_{2} ; \mathrm{ML}^{\circledR} 9850 \mathrm{~B}\right.$ UV, Teledyne, USA), and nitrogen oxides $\left(\mathrm{NO}_{2}\right.$ and $\mathrm{NO} ; \mathrm{ML}^{\circledR} 9841$, Teledyne, USA) concentration inside each chambers and AA plots were monitored continuously above 
Table 1

Species composition of the experimental annual pasture community.

\begin{tabular}{|c|c|c|c|c|c|c|c|}
\hline Species & Family & Seed source & $\begin{array}{l}\text { Percentage in } \\
\text { the mix }{ }^{c}\end{array}$ & $\begin{array}{l}\text { Seed germinative } \\
\text { rate }(\%)\end{array}$ & $\begin{array}{l}100 \text { Seed } \\
\text { weight }(g)\end{array}$ & Ozone sensitivity & Reference \\
\hline Trifolium striatum & Leguminosae & Seed bank ${ }^{\mathrm{a}}$ & 15 & 88 & 0.234 & sensitive & Sanz et al., 2007 \\
\hline Trifolium cherleri & Leguminosae & Seed bank ${ }^{\mathbf{a}}$ & 15 & 96 & 0.285 & sensitive & Sanz et al., 2007 \\
\hline Ornithopus compressus & Leguminosae & Seed bank $\mathbf{k}^{\mathbf{a}}$ & 15 & 57 & 0.156 & resistant & Bermejo et al., 2003 \\
\hline Cynosurus echinatus & Gramineae & D. Moncalvillo ${ }^{\mathrm{b}}$ & 22.5 & 88 & 0.133 & resistant & Gimeno et al., 2004a,b \\
\hline Briza maxima & Gramineae & D. Moncalvillo ${ }^{\mathrm{b}}$ & 22.5 & 93 & 0.273 & Rel. resistant & Sanz et al., 2011 \\
\hline Silene gallica & caryophylaceae & D. Moncalvillo ${ }^{\mathrm{b}}$ & 10 & 76 & 0.041 & unknown & \\
\hline
\end{tabular}

${ }^{a}$ Bank of Extremadura Community Agriculture Department (seeds from central-western areas of the Iberian Peninsula; $T$. striatum: $38^{\circ} 55^{\prime} \mathrm{N}, 05^{\circ} 06^{\prime} \mathrm{W} ;$ T. cherleri: $38^{\circ} 22^{\prime} \mathrm{N}$, $0^{\circ} 64^{\prime} \mathrm{W} ; 0$. compressus: $38^{\circ} 55^{\prime} \mathrm{N}, 05^{\circ} 06^{\prime} \mathrm{W}$ )

${ }^{\mathrm{b}}$ Dehesa de Moncalvillo, Guadalix de la Sierra, Madrid $\left(40^{\circ} 40^{\prime} \mathrm{N}, 03^{\circ} 46^{\prime} \mathrm{W}\right)$.

c Weight based.

the canopy ( $50 \mathrm{~cm}$ above the soil) using an automated time-sharing system which sampled each plot for $10 \mathrm{~min}$. The accumulated $\mathrm{O}_{3}$ exposure was characterized by the AOT40 index representing the accumulated exposure over a threshold of $40 \mathrm{nl}^{-1}$ during daylight hours. Micro-meteorological stations were installed inside the AA plots, FA and NFA ++ chambers for continuously monitoring air relative humidity $(\mathrm{RH})$ and temperature (HOBO ${ }^{\mathbb{Q}}$ Pro v2, Onset), photosynthetic active radiation (PAR; OSO-SUN HOBO ${ }^{\mathbb{B}}$, Onset, USA), soil relative humidity (ECHO 10, Decagon Devices, USA) and soil temperature (TMC6-HD $\mathrm{HOBO}^{\mathbb{\mathbb { }}}$, Onset, USA) at $10-15 \mathrm{~cm}$ depth.

Immediately after seed sowing (February 11, 2011), all experimental plots were divided in three sectors $\left(1.4 \mathrm{~m}^{2}\right.$ each) delimiting the three $\mathrm{N}$ input treatments: NO (soil $\mathrm{N}$ background), N20 $\left(20 \mathrm{~kg} \mathrm{~N} \mathrm{ha}^{-1}\right.$ ) and $\mathrm{N} 40\left(40 \mathrm{~kg} \mathrm{~N} \mathrm{ha}^{-1}\right)$. To reach these integrated doses, $\mathrm{N}$ supplementation was applied every 2 -weeks using an ammonium nitrate $\left(\mathrm{NH}_{4} \mathrm{NO}_{3}\right)$ solution (Table 2). Trying to keep the natural limited water conditions of annual pastures, watering was only lightly applied when strictly necessary, i.e. after sowing, with $\mathrm{N}$ applications ( 31 water $\mathrm{m}^{-2}$ for each $\mathrm{N}$ application) or when an excessive water stress was detected that could compromise the experiment. Nitrogen content of the water supplied was periodically controlled being always close to zero. A total volume of 481 water $\mathrm{m}^{-2}$ during the whole experimental period was applied; thus, incrementing about $30 \%$ the natural precipitation experienced during the growing season.

Table 2

Timetable of the experimental events.

\begin{tabular}{|c|c|c|c|}
\hline Event & Date & $\mathrm{DaE}^{\mathrm{a}}$ & $\mathrm{DaS}^{\mathrm{b}}$ \\
\hline Sowing & 11-Feb & & \\
\hline Emergence & 25-Feb & 1 & \\
\hline First harvest (vegetative stage) & 11-Apr & 46 & 0 \\
\hline Start of ozone exposure & 12-Apr & 47 & 1 \\
\hline $\begin{array}{l}\text { Gas exchange sampling } \\
\text { (vegetative stage) }\end{array}$ & $12 / 14 \mathrm{Apr}$ & $47(46-48)$ & $0-2$ \\
\hline First $\mathrm{N}$ fertilization & 13-Apr & 48 & 2 \\
\hline Second $\mathrm{N}$ fertilization & 26-Apr & 61 & 15 \\
\hline $\begin{array}{l}\text { Gas exchange sampling } \\
\text { (reproductive stage) }\end{array}$ & 27/28 April & $62(62-63)$ & $16-17$ \\
\hline Third $N$ fertilization & 10-May & 75 & 34 \\
\hline $\begin{array}{l}\text { Second harvest (reproductive } \\
\text { stage)/leaf damage } \\
\text { quantification }\end{array}$ & 20-May & 85 & 39 \\
\hline Fourth $\mathrm{N}$ fertilization & 24-May & 89 & 43 \\
\hline $\begin{array}{l}\text { Gas exchange sampling } \\
\text { (senescence stage) }\end{array}$ & 25-27 May & $91(89-93)$ & $44-48$ \\
\hline End of ozone exposure & 30-May & 95 & 49 \\
\hline $\begin{array}{l}\text { Third harvest (senescence and } \\
\text { seed maturity) }\end{array}$ & 20-Jun & 116 & 70 \\
\hline
\end{tabular}

Numbers in brackets indicate the real range of the sampling period for a particular parameter.

${ }^{a} \mathrm{DaE}=$ Days after emergence.

${ }^{\mathrm{b}} \mathrm{DaS}=$ Days after start of ozone exposure
Plant exposure to the different $\mathrm{O}_{3}$ treatments started in April, 47 days after emergence (DaE; Table 2). Almost at the same time (48 $\mathrm{DaE}$ ), the first $\mathrm{N}$ fertilization was applied. Pasture was exposed to $\mathrm{O}_{3}$ for 49 days until the community reached its maximum development and productivity, then the $\mathrm{O}_{3}$ exposure system was switched off allowing plants to dry up and complete seed maturation which happened at the end of May.

Total soil mineral $\mathrm{N}\left(\mathrm{N}_{\text {min }}\right)$ content $\left(\mathrm{NO}_{3}^{-}+\mathrm{NH}_{4}^{+}\right)$was analyzed throughout the experiment within the top $20 \mathrm{~cm}$ of the upper soil horizon. After the extraction of $8 \mathrm{~g}$ of mixed fresh soil with $50 \mathrm{ml}$ of water and $50 \mathrm{ml}$ of $1 \mathrm{M} \mathrm{KCl}$ solution, $\mathrm{NO}_{3}^{-}$and $\mathrm{NH}_{4}^{+}$concentrations were measured with an Orion $720 \mathrm{~A}$ electrode (Thermo Fisher Scientific, Beverly, MA, USA) and with a Technicon AAII Auto-analyser (Technicon Hispania, Madrid, Spain) respectively.

\subsection{Visible injury}

Visible leaf damage was evaluated on the second harvest (Table 2) based on the percentage of damaged leaves per plant. All the plants inside one sampling harvest ring $\left(5 \mathrm{dm}^{2}\right)$ per chamber and $\mathrm{N}$ treatment were evaluated. Ozone-induced foliar damage was quantified as the percentage of damaged leaves per plant relative to the total considering four classes: no injury, $0-25 \%, 25-50 \%$, $50-75 \%$ and $75-100 \%$ of leaves affected. A leaf damage index for the community $\left(\mathrm{LDI}_{\mathrm{C}}\right)$ was calculated based on the foliar mean damage for each individual species weighted by its own abundance. Abundance per species was estimated from their green biomass proportion inside the sampling ring.

\subsection{Biomass harvest}

Aboveground biomass production was harvested three times throughout the life cycle of the pasture (Table 2). The early harvest was done just before the start of $\mathrm{O}_{3}$ treatments and $\mathrm{N}$ applications (46 DaE), signaling the initial stage of the pasture (Vegetative Stage). The second harvest was collected after 39 days of $\mathrm{O}_{3}$ exposure (85 DaE), when the pasture reached its maximum biomass and flowering development (Reproductive Stage). After this harvest, the $\mathrm{O}_{3}$ fumigation system was switched off coinciding with the start of pasture natural decline. The last harvest was done when plant biomass was completely dried and seeds reached maturity (116 DaE, Senescence and seed maturity Stage). For each harvest, all plants within a $5 \mathrm{dm}^{2}$ sampling ring were cautiously collected per chamber and $\mathrm{N}$ treatment. Plant material was classified into species (data not shown) and immediately weighed to obtain fresh weight biomass. Afterwards, samples were dried to constant weight at $60^{\circ} \mathrm{C}$. Additionally, in the second harvest, green and senescent leaves were separated and root biomass was extracted by hand from the first $10 \mathrm{~cm}$ of soil collected inside the sampling ring. 


\subsection{Gas exchange at canopy level}

Gas exchange at canopy level was measured using a steady-state custom-made cuvette coupled to the Li-Cor 6400 portable gas exchange system (Li-Cor, Nebraska, USA) following the company technical recommendations (García et al., 1990). A cylindrical cuvette was made of transparent methacrylate $(24.5 \mathrm{~cm}$ radius, $29.4 \mathrm{~cm}$ height), covered with a polypropylene film to moderate temperature increments. The inside walls of the cuvette were coated with Teflon ${ }^{\circledR}$ tape to avoid condensation and water absorption and desorption on the walls. The open bottom allows the cuvette to be placed over the pasture. Two fans were set inside to facilitate air mixing. PAR (LI-190, LI-COR Inc, USA), air temperature and RH (Vaisala Inc. USA) were continuously monitored inside the cuvette. Air flow to the cuvette was propelled using an external pump (KNF NMP $830 \mathrm{KVDE} 12 \mathrm{~V}, \mathrm{KNF}$ ) and the inlet air flow was continuously monitored with an air velocity transducer (TSI 8455 , TSI Inc., USA).

Gas exchange measurements were performed between 9:00-11:00 h GMT on clear sunny days at the three different pasture development stages (Table 2). During the Reproductive Stage, NFA was not measured due to bad weather conditions. Gas exchange measures were acquired only when the steady-stationary state was achieved which took around $2 \mathrm{~min}$. Afterwards, instantaneous values were averaged for $2 \mathrm{~min}$. Bare soil measures without plants inside the sampling ring were done at Senescence Stage in plots previously harvested and left without plants for one month. Ecosystem $\mathrm{CO}_{2}$ Exchange (NEE) was calculated on ground surface area basis ( $\mu \mathrm{mol} \mathrm{CO}_{2} \mathrm{~m}^{-2} \mathrm{~s}^{-1}$ ) and on dry biomass basis ( $\mu \mathrm{mol} \mathrm{CO} 2 \mathrm{~g} \mathrm{dw}^{-1} \mathrm{~s}^{-1}$ ) using the biomass harvest data collected at the different phenological stages. After each full-light steady-state NEE measurement, cuvette was completely darkened with a black cloth to record the steady-state ecosystem Dark Respiration $\left(\underline{R}_{e c o}\right)$. Gross Primary Production (GPP) was estimated according to: $\mathrm{GPP}=\mathrm{NEE}-R_{\text {eco }}$. Two measures per OTC and $\mathrm{N}$ treatment were done. After the measurements, plants inside the cuvette were harvested for biomass analyses.

\subsection{Statistical analysis}

The effects of $\mathrm{N}$ fertilization and $\mathrm{O}_{3}$ exposure on the different response parameters and harvests were evaluated with Analysis of Variance (ANOVA) using a split-plot design, considering $\mathrm{O}_{3}$ as the main factor, $\mathrm{N}$ as sub-factor and their interaction. A block effect was also included as a random factor. A phenological stage factor was considered to analyze gas exchange rates. Annual pastures did not grow again after harvest, thus different sampling rings were selected for each harvest assuring its independence for statistical purposes. When significant differences among treatments were detected $(p<0.05)$, mean differences were assessed with the Tukey Honestly Significant Difference test (HSD). Normal probability plots and scatter plots of residuals were used to test normality. The Levenne test was applied to check variance homoscedasticity. When data did not fulfill model requirements, data were logtransformed. Outliers were rejected based on studentized residuals procedure (if greater than 3 ). All statistical analyses were carried out using the Statistica v.11 (StatSoft Inc., USA).

\section{Results}

\subsection{Ozone exposure, meteorological and soil conditions}

Ozone was the most important air pollutant in this area with $\mathrm{SO}_{2}$ and $\mathrm{NO}_{x}$ concentrations always within the range of monitor detection limits ( $1 \mathrm{nl} \mathrm{l^{-1 }}$; data not shown). Ambient $\mathrm{O}_{3}$ concentrations increased from March to June (Fig. 1) reaching the hourly maximum of $68 \mathrm{nl} \mathrm{l}^{-1}$ in April (Table 3, Fig. 1). Ozone exposure indices and mean daily profiles for the different $\mathrm{O}_{3}$ treatments are presented in Table 3 and Fig. 1 respectively. No significant differences among chambers or $\mathrm{O}_{3}$ treatments were detected on prevailing meteorological conditions (Table 3 ).

Total soil mineral $\mathrm{N}$ background represented in NO treatment was stable throughout the experiment averaging $10 \mathrm{mg} \mathrm{N} \mathrm{N}_{\min } \mathrm{kg}^{-1}$ (Fig. 2). Soil $\mathrm{N}$ content increased with each $\mathrm{N}$ dose, and values remained slightly higher than before the $\mathrm{N}$ addition. At the end of the experiment, $\mathrm{N} 20$ and $\mathrm{N} 40$ presented $18 \mathrm{mg} \mathrm{N} \mathrm{Nin}_{\text {kg }}^{-1}$ and $27 \mathrm{mg} \mathrm{N}_{\min } \mathrm{kg}^{-1}$ respectively (means across $\mathrm{O}_{3}$ ) compared to the background $10 \mathrm{mg} \mathrm{N} \mathrm{N}_{\min } \mathrm{kg}^{-1}$.

\subsection{Visible foliar injury}

Different $\mathrm{O}_{3}$-injury typology was observed depending on plant family: Leguminosae species showed brown-reddish necrotic spots on the upper surface of mature leaves; Gramineae species exhibited necrotic leaf tips and an obvious increase in foliar senescence; Silene showed similar symptoms to clover although very scarce. No $\mathrm{O}_{3}$-induced visible injury was registered on plants exposed to ambient $\mathrm{O}_{3}$ levels (NFA treatment), nevertheless $\mathrm{O}_{3}$ significantly increased $\mathrm{LDI}_{\mathrm{C}}$ by $31 \%$ and $48 \%$ in NFA+ and NFA++ treatments respectively compared with FA (mean across $\mathrm{N}$ treatments; Table 4). No significant differences were observed among $N$ treatments, neither $\mathrm{N}$ modulated the foliar injury response to ozone (Table 4).

\subsection{Biomass}

The pasture life cycle experienced a slow growing period during the first 45 days (February-March, growth rate of $1.7 \mathrm{~g} \mathrm{dw}_{\text {day }}{ }^{-1}$; Fig. 3), then a very fast and short growing period during April until mid-May (46-85 DaE, mean growth rate across $\mathrm{O}_{3}$ and $\mathrm{N}$ treatments of $\left.8.5 \mathrm{~g} \mathrm{dw} \mathrm{day}^{-1}\right)$, and finally pasture growth rate declines until mid-June (86-116 DaE, average growth rate of $4.4 \mathrm{~g} \mathrm{dw}$ day $^{-1}$ ), when plants were completely dry.

The first aboveground biomass harvest was sampled before starting the $\mathrm{O}_{3}$ exposure, in order to test pasture growth homogeneity in all the experimental plots. At this time, seedlings showed a very low yield with a mean value across $\mathrm{O}_{3}$ and $\mathrm{N}$ treatments of $76 \mathrm{~g} \mathrm{dw} \mathrm{m}^{-2}$, representing $14 \%$ of the total pasture yield at the end of the growing cycle. No significant differences were found among chambers, although differences between OTCs and AA plots were significant at this early time (see Appendix).

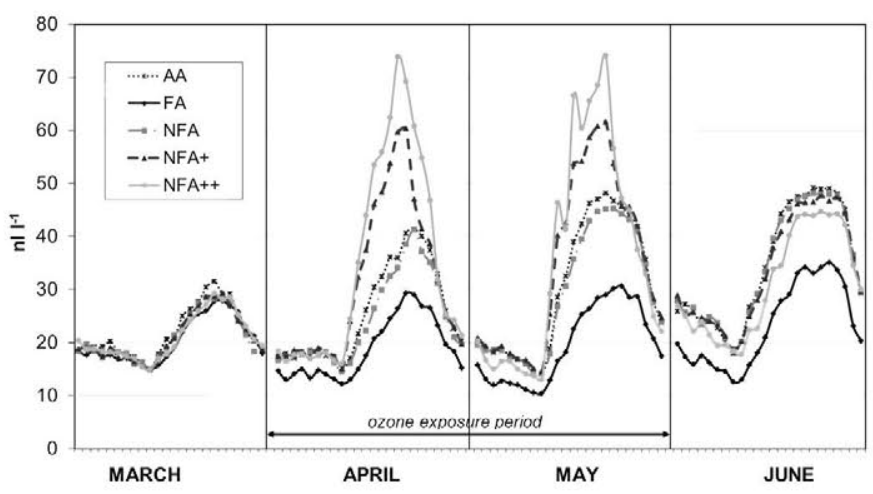

Fig. 1. Mean daily profiles of ozone concentration in the different treatments during the experimental period: $\mathrm{AA}=$ Ambient plots without chamber, $\mathrm{FA}=$ charcoal filtered air, NFA $=$ non filtered air, NFA $+=$ non filtered air supplemented with $20 \mathrm{nl} \mathrm{l}^{-1}$ of $\mathrm{O}_{3}$. $\mathrm{NFA}++=$ non filtered air supplemented with $40 \mathrm{nl}^{-1}$ of $\mathrm{O}_{3}$. 
Table 3

Summary of the meteorological conditions and $\mathrm{O}_{3}$ exposure indexes for the different $\mathrm{O}_{3}$ treatments during the growing season (from February 25 to June 20) and during the maximum growth period (April-June). $\mathrm{RH}=$ relative air humidity; PAR = Photosynthetic Active Radiation; VPD = Atmospheric Vapor Pressure Deficit; $F A=$ charcoal filtered air; NFA $=$ non filtered air; NFA $+=$ non filtered air $+20 \mathrm{nl}^{-1}$ of $\mathrm{O}_{3} ; \mathrm{NFA}++=$ non filtered air $+40 \mathrm{nl} \mathrm{l}^{-1}$ of $\mathrm{O}_{3}$.

\begin{tabular}{|c|c|c|c|c|c|c|c|c|c|}
\hline \multicolumn{10}{|c|}{ Meteorological conditions } \\
\hline & & \multicolumn{5}{|c|}{ February-June } & \multicolumn{3}{|l|}{ April-June } \\
\hline & & \multicolumn{2}{|c|}{24 h-mean } & \multicolumn{2}{|c|}{$\operatorname{Max}$} & \multirow{2}{*}{$\frac{\operatorname{Min}}{-1.5}$} & 24 h-mean & Max & Min \\
\hline \multicolumn{2}{|c|}{ Temperature $\left({ }^{\circ} \mathrm{C}\right)$} & \multicolumn{2}{|c|}{16.1} & \multicolumn{2}{|c|}{36.4} & & 18.8 & 36.4 & 6.1 \\
\hline \multicolumn{2}{|l|}{$\mathrm{RH}(\%)$} & \multicolumn{2}{|c|}{65.6} & \multicolumn{2}{|c|}{99.6} & 17.5 & 61.1 & 99.2 & 17.5 \\
\hline \multicolumn{2}{|c|}{$\operatorname{PAR}\left(\mu \mathrm{ml} \mathrm{m} \mathrm{m}^{-2} \mathrm{~s}^{-1}\right)$} & \multicolumn{2}{|c|}{476.9} & \multicolumn{2}{|c|}{2248.2} & 0 & 550.7 & 2248.2 & 0 \\
\hline \multicolumn{2}{|c|}{ VPD (Kpa) } & \multicolumn{2}{|c|}{1.08} & \multicolumn{2}{|c|}{6.33} & 0 & 1.35 & 6.33 & 0.03 \\
\hline \multicolumn{2}{|c|}{ Soil temp. $\left({ }^{\circ} \mathrm{C}\right)$} & \multicolumn{2}{|c|}{17.2} & \multicolumn{2}{|c|}{31.6} & 4.2 & 20.1 & \multirow{2}{*}{$\begin{array}{l}31.6 \\
27.1\end{array}$} & 13.2 \\
\hline \multirow{2}{*}{\multicolumn{2}{|c|}{$\begin{array}{l}\text { Soil humidity (\%) } \\
\text { Precipitation (mm) }\end{array}$}} & \multicolumn{2}{|c|}{21.7} & \multicolumn{2}{|c|}{40.1} & 18 & 20.1 & & 18.0 \\
\hline & & 148 & & & & & 97.7 & & \\
\hline \multicolumn{10}{|c|}{ Ozone indexes } \\
\hline & \multicolumn{2}{|c|}{$\begin{array}{l}24 \text { h-mean } \\
\left(\mathrm{nl} \mathrm{l}^{-1}\right)\end{array}$} & \multicolumn{2}{|c|}{$\begin{array}{l}\text { Hourly } \\
\text { maximum } \\
\left(\mathrm{nl}^{-1}\right)\end{array}$} & & $\begin{array}{l}- \text { mean } \\
\left.1^{-1}\right)\end{array}$ & $\begin{array}{l}\text { Febr.-Jun } \\
\text { AOT40 } \\
\left(\mathrm{nl} \mathrm{l}^{-1} \mathrm{~h}\right)\end{array}$ & $\begin{array}{l}\text { Apri } \\
\text { AOT } \\
\text { (nl l }\end{array}$ & $\begin{array}{l}\text { 1-June } \\
40 \\
-1 \text { h) }\end{array}$ \\
\hline $\mathrm{AA}$ & 29 & & 68 & & 36 & & 3780 & 37 & 37 \\
\hline FA & 20 & & 48 & & 23 & & 174 & & 58 \\
\hline NFA & 28 & & 65 & & 34 & & 2805 & 27 & 98 \\
\hline NFA+ & 33 & & 138 & & 45 & & 9205 & 91 & 73 \\
\hline $\mathrm{NFA}++$ & 34 & & 189 & & 50 & & 14,257 & 14,2 & \\
\hline
\end{tabular}

a Total precipitation.

At the second aboveground biomass harvest (Table 4), the mean yield of the pasture was $406 \mathrm{~g} \mathrm{dw} \mathrm{m}^{-2}$ (overall mean across $\mathrm{O}_{3}$ and $\mathrm{N}$ treatments); thus, the accumulated biomass from the emergence represented $75 \%$ of the total yield at the end of the life of the pasture. Ozone caused stronger effects than $\mathrm{N}$ in all the biomass parameters evaluated since the $\mathrm{O}_{3}$ factor accounted for $43-55 \%$ (depending of the parameter) of the total variability of the data compared with the $<3 \%$ assigned to the $\mathrm{N}$ factor, $16-17 \%$ to the interaction and $14 \%$ to the block effect caused by the soil heterogeneity of the field. Green, senescent and total aboveground biomass were negatively affected by $\mathrm{O}_{3}$ exposure (Table 4). Significant reductions on green biomass of $7 \%, 14 \%$ and $25 \%$ were detected in NFA, NFA + and NFA ++ treatments respectively compared with FA (means across all $\mathrm{N}$ treatments), although the differences between FA and NFA treatments were not statistically significant. Ozone increased $40 \%$ the senescent biomass in both $\mathrm{NFA}+$ and NFA ++ compared to FA, resulting in a strong increment up to $90 \%$ in the NFA++ treatment of the senescent/green biomass ratio (Fig. 4). When total yield was considered, $\mathrm{O}_{3}$ exposure induced $9 \%, 11 \%$ and $21 \%$ reductions in NFA, NFA + and NFA++ respectively

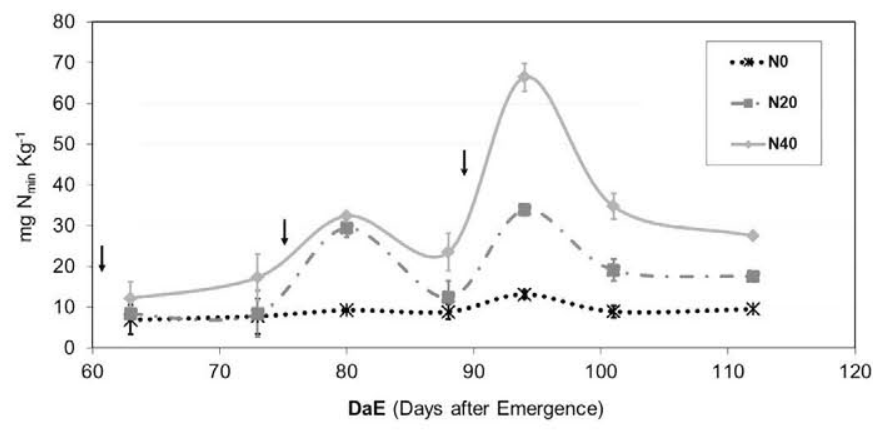

Fig. 2. Total soil $N$ mineral content $\left(N_{\min }\right)$ for the different $N$ treatments (means across $\mathrm{O}_{3}$ treatments $\left.\pm \mathrm{se}\right)$. Arrows indicate the addition of the different $\mathrm{N}$ dose supplementation. $\mathrm{NO}=$ soil background; $\mathrm{N} 20=20 \mathrm{~kg} \mathrm{~N} \mathrm{ha}^{-1} ; \mathrm{N} 40=40 \mathrm{~kg} \mathrm{~N} \mathrm{ha}^{-1}$. (mean across $\mathrm{N}$ treatments). No significant $\mathrm{O}_{3}$ effects were detected on the fresh/dry weight ratio of green biomass (Table 4).

Nitrogen fertilization treatments did not cause any significant effect on biomass parameters in the second harvest. However, a significant interaction between $\mathrm{O}_{3}$ and $\mathrm{N}$ was detected on green and total aboveground biomass (Table 4). While no differences among $\mathrm{O}_{3}$ treatments were detected in the NO treatment, NFA+ and $\mathrm{NFA}++$ green biomass were significantly lower than FA in N20, and $\mathrm{NFA}++$ biomass was significantly lower than FA and NFA in the N40 treatment (Fig. 5). Increasing $\mathrm{N}$ availability enhanced green biomass production mainly in FA and NFA, becoming higher than in the treatments supplemented with $\mathrm{O}_{3}$. Thus, $\mathrm{O}_{3}$ exposure reduced the fertilization effect of $\mathrm{N}$ additions. On the other hand, higher $\mathrm{N}$ availability in $\mathrm{N} 40$ decreased the $\mathrm{O}_{3}$ induced effects on green biomass when $\mathrm{O}_{3}$ concentrations were moderate, but not with high $\mathrm{O}_{3}$ levels since green biomass in NFA ++ was still significantly lower than in FA. Total biomass followed exactly the same statistical pattern as green biomass. The observed differences between OTCs and $A A$ found in the earlier harvest disappeared in the second harvest (See Appendix).

A third aboveground biomass harvest was collected at the end of the life span of the pasture when all the species were completely dry. At this stage, a $19 \%$ yield reduction was observed in NFA++ compared with FA (Fig. 3), although this difference represented only a statistical trend $(p<0.1)$. No significant effect of the $\mathrm{N}$ treatments was observed on pasture yield at this harvest, neither a significant $\mathrm{O}_{3} \times \mathrm{N}$ interaction.

Mean pasture root biomass per square meter collected at the second harvest was $37 \mathrm{~g} \mathrm{dw} \mathrm{m}^{-2}$ giving a mean root/aerial biomass rate of 0.1 (means across $\mathrm{O}_{3}$ and $\mathrm{N}$ treatments). No significant effects caused by $\mathrm{O}_{3}$, $\mathrm{N}$ or their interaction could be detected on root biomass or root/aboveground biomass ratio (Table 4).

\subsection{Canopy gas exchange}

NEE was affected by both $\mathrm{O}_{3}$ and phenological stage factors without interactive effects between them (Table 5). No significant effects of the different $\mathrm{N}$ treatments were detected. NEE showed maximum values at the Reproductive Stage, when the pasture reached its maximum growth development. At this stage, mean values across $\mathrm{N}$ treatment averaged $26 \mu \mathrm{mol} \mathrm{CO} \mathrm{m}^{-2} \mathrm{~s}^{-1}$ (Fig. 6). During the Senescence Stage, NEE was reduced to $9 \mu \mathrm{mol} \mathrm{CO} 2 \mathrm{~m}^{-2} \mathrm{~s}^{-1}$, thus 64\% lower compared to the maximum (means across $\mathrm{O}_{3}$ and $\mathrm{N}$ treatments). Ozone exposure induced a reduction of $28 \%$ of NEE throughout the growing cycle compared with FA (mean across $\mathrm{N}$ treatments and phenological stages), and $\mathrm{O}_{3}$ ambient levels (NFA) were enough to produce this effect (Table 5). When NEE was expressed in terms of dry biomass ( $\mu \mathrm{mol}$ $\mathrm{CO}_{2} \mathrm{~g} \mathrm{dw}^{-1} \mathrm{~s}^{-1}$ ), the $\mathrm{O}_{3}$ induced differences were significant only at the Vegetative Stage (Fig. 6b). Interestingly, maximum NEE values based on dry biomass were reached in the earlier stages of the pasture, diminishing progressively until pasture senescence (Fig. 6).

Dark respiration $\left(\mathrm{R}_{\mathrm{eco}}\right)$ was relatively stable across $\mathrm{O}_{3}$ and phenological stages (Table 5; Fig. 6) and no differences were detected caused by $\mathrm{N}$ treatments. However, when expressed in terms of dry weight biomass, both $\mathrm{O}_{3}$ and phenological stage factors affected $R_{\text {eco }}$ (Fig. 6): at the Vegetative Stage, $R_{\text {eco }}$ in NFA++ treatment doubled the value of the FA control (mean across $\mathrm{N}$ treatments). This effect was also observed during the Senescence Stage. Average respiration of bare soil $\left(\mathrm{CO}_{2}\right.$ flux without plants inside the sampling ring) was $-2.2 \mu \mathrm{mol} \mathrm{CO} \mathrm{Cm}^{-2} \mathrm{~s}^{-1}$, representing about $28 \%$ of the average $R_{\text {eco }}$ of the canopy pasture $\left(-7.82 \mu \mathrm{mol} \mathrm{CO} \mathrm{CO}_{2} \mathrm{~m}^{-2} \mathrm{~s}^{-1}\right.$, average value across $\mathrm{O}_{3}$ and $\mathrm{N}$ treatments). GPP presented the same phenological pattern as NEE, with maximum values recorded during the peak growing season 
Table 4

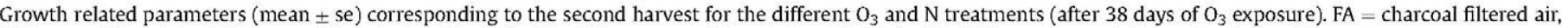

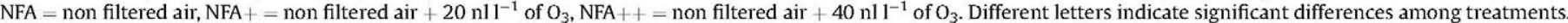

\begin{tabular}{|c|c|c|c|c|c|c|c|}
\hline & $\begin{array}{l}\text { Canopy leaf damage } \\
\text { index }(\%)\end{array}$ & $\begin{array}{l}\text { Senescent biomass } \\
\left(\mathrm{g} \mathrm{dw}^{-2}\right)\end{array}$ & $\begin{array}{l}\text { Total aboveground } \\
\text { biomass }\left(\mathrm{g} \mathrm{dw} \mathrm{m}^{-2}\right)\end{array}$ & $\begin{array}{l}\text { Root biomass } \\
\left(\mathrm{g} \mathrm{dw} \mathrm{m}^{-2}\right)\end{array}$ & $\begin{array}{l}\text { Fresh/dry aerial } \\
\text { biomass ratio }\end{array}$ & $\begin{array}{l}\text { Senescent/green } \\
\text { biomass ratio }\end{array}$ & $\begin{array}{l}\text { Root/aerial } \\
\text { biomass ratio }\end{array}$ \\
\hline \multicolumn{8}{|l|}{ Experimental factors } \\
\hline Ozone & $<0.005$ & $<0.05$ & $<0.05$ & ns & ns & $<0.05$ & ns \\
\hline Nitrogen & ns & ns & ns & ns & ns & ns & ns \\
\hline Nitrogen $\times$ Ozone & ns & ns & $<0.05$ & ns & ns & ns & ns \\
\hline $\begin{array}{l}\text { Block } \\
\text { Mean values }\end{array}$ & ns & \multicolumn{3}{|c|}{ Mean values } & ns & ns & ns \\
\hline FA NO & 0 & $20.1 \pm 3.1$ & $417.9 \pm 17.0^{\mathrm{abc}}$ & $37.7 \pm 8.5$ & $19.2 \pm 2.0$ & $0.05 \pm 0.01$ & $0.09 \pm 0.02$ \\
\hline NFA NO & 0 & $20.8 \pm 6.9$ & $382.6 \pm 14.6^{\mathrm{bc}}$ & $36.3 \pm 5.6$ & $20.9 \pm 1.9$ & $0.06 \pm 0.02$ & $0.10 \pm 0.02$ \\
\hline $\mathrm{NFA}+\mathrm{NO}$ & $30.3 \pm 3.9$ & $48.5 \pm 7.5$ & $414.1 \pm 11.1^{\mathrm{bc}}$ & $38.3 \pm 7.4$ & $17.7 \pm 2.0$ & $0.13 \pm 0.02$ & $0.10 \pm 0.02$ \\
\hline $\mathrm{NFA}++\mathrm{N} 0$ & $45.1 \pm 2.7$ & $42.5 \pm 2.3$ & $380.4 \pm 10.6^{\mathrm{bc}}$ & $44.4 \pm 14.9$ & $21.1 \pm 1.0$ & $0.13 \pm 0.01$ & $0.13 \pm 0.05$ \\
\hline FA N20 & 0 & $32.9 \pm 7.5$ & $495.2 \pm 20.3^{a}$ & $39.1 \pm 2.4$ & $19.7 \pm 0.4$ & $0.07 \pm 0.02$ & $0.09 \pm 0.01$ \\
\hline NFA N20 & 0 & $16.1 \pm 6.0$ & $404.5 \pm 23.5^{\mathrm{bc}}$ & $36.5 \pm 3.1$ & $20.2 \pm 1.8$ & $0.04 \pm 0.01$ & $0.09 \pm 0.00$ \\
\hline $\mathrm{NFA}+\mathrm{N} 20$ & $36.7 \pm 3.4$ & $35.7 \pm 17.5$ & $393.4 \pm 46.6^{\mathrm{bc}}$ & $42.9 \pm 8.2$ & $20.4 \pm 0.4$ & $0.1 \pm 0.04$ & $0.12 \pm 0.03$ \\
\hline $\mathrm{NFA}++\mathrm{N} 20$ & $47.3 \pm 4.1$ & $36.6 \pm 7.6$ & $349.4 \pm 39.5^{c}$ & $23.6 \pm 0.9$ & $22.1 \pm 1.1$ & $0.12 \pm 0.03$ & $0.08 \pm 0.01$ \\
\hline FA N40 & 0 & $28.3 \pm 10.5$ & $442.0 \pm 19.2^{\mathrm{ab}}$ & $47.0 \pm 14.6$ & $20.3 \pm 3.0$ & $0.07 \pm 0.02$ & $0.11 \pm 0.04$ \\
\hline NFA N40 & 0 & $17.5 \pm 1.8$ & $450.6 \pm 18.9^{\mathrm{ab}}$ & $36.6 \pm 0.6$ & $21.3 \pm 0.7$ & $0.04 \pm 0.01$ & $0.08 \pm 0.01$ \\
\hline $\mathrm{NFA}+\mathrm{N} 40$ & $26.1 \pm 2.6$ & $30.4 \pm 5.3$ & $404.0 \pm 26.0^{\mathrm{bc}}$ & $33.5 \pm 4.7$ & $20.0 \pm 1.1$ & $0.08 \pm 0.02$ & $0.09 \pm 0.01$ \\
\hline $\mathrm{NFA}++\mathrm{N} 40$ & $51.1 \pm 3.9$ & $35.4 \pm 6.1$ & $344.4 \pm 25.1^{c}$ & $28.9 \pm 5.4$ & $22.1 \pm 1.5$ & $0.11 \pm 0.01$ & $0.10 \pm 0.02$ \\
\hline
\end{tabular}

(Reproductive Stage). Ozone reduced pasture GPP, being the $\mathrm{NFA}++$ values $80 \%$ significantly lower than FA (Table 5). At the end of the growing cycle (Senescence Stage), due to the $\mathrm{O}_{3}$-induced increment of $R_{\mathrm{eco}}$, only FA sustained a positive gas exchange balance (Fig. 6).

\section{Discussion}

To our knowledge, the present experiment is the first one studying the response of an experimental annual pasture community to increased $\mathrm{O}_{3}$ and $\mathrm{N}$ levels growing under natural soil conditions and allowing plant competition. Although growing inside OTCs, the pasture followed a similar development to pastures growing under natural conditions in the Central Iberian Peninsula. The average yield of the experimental pasture at maximum development was $406 \mathrm{~g} \mathrm{dw} \mathrm{m}^{-2}$, equivalent to $4060 \mathrm{~kg}$ dry matter $\mathrm{ha}^{-1}$. This value is within the range of $500-5400 \mathrm{~kg}$ dry matter $\mathrm{ha}^{-1}$ year $^{-1}$ reported under natural conditions (Olea and SanMiguel-Ayanz, 2006; Vázquez-De-Aldana et al., 2008; Hussain et al., 2009). Likewise, NEE and dark respiration rates were similar to values measured in natural annual pastures in Portugal (Hussain

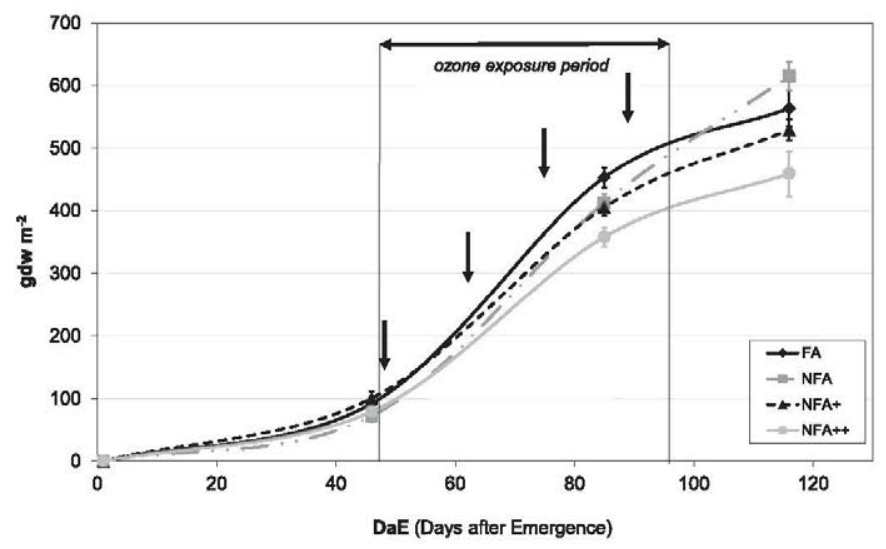

Fig. 3. Total aboveground biomass of the pasture for the different $\mathrm{O}_{3}$ treatments since emergence till the end of the life span (means across $\mathrm{N}$ treatments $\pm \mathrm{se}$ ). FA = charcoal filtered air, NFA $=$ non filtered air, NFA $+=$ non filtered air supplemented with $20 \mathrm{nl} \mathrm{l}^{-1}$ of $\mathrm{O}_{3}$, NFA++ $=$ non filtered air supplemented with $40 \mathrm{nl} \mathrm{l}^{-1}$ of $\mathrm{O}_{3}$. Arrows indicate the time of $\mathrm{N}$ addition. et al., 2009). Therefore, our experimental annual community can be considered representative of natural annual pastures.

Ozone clearly affected the annual pasture community causing visible foliar injury, accelerating plant senescence and reducing green and total aboveground biomass. Ozone induced foliar visible damage in $30 \%-48 \%$ of the canopy and decreased up to $25 \%$ of green biomass and up to $21 \%$ of total aboveground biomass. Interestingly, even ambient $\mathrm{O}_{3}$ levels (NFA treatment) showed a clear trend to reduce total aboveground biomass of the annual community (9\%). These results agree with previous studies performed with individual annual species or two-species mesocosms showing $\mathrm{O}_{3}$-induced reductions on growth parameters within the range 20-30\% in some sensitive species (Gimeno et al., 2004a,b; Sanz et al., 2005, 2007). Thus, the response to $\mathrm{O}_{3}$ observed in an annual community was in the range of the effects reported for individual species. By contrast, well established perennial grassland communities have shown higher resilience to $\mathrm{O}_{3}$ effects when comparing to individual component species (Volk et al., 2006; Stampfli and Fuhrer, 2010). On the other hand, our experimental annual community seemed to be more sensitive to $\mathrm{O}_{3}$ that perennial grasslands since significant effects were detected after few weeks of $\mathrm{O}_{3}$ exposure. Volk et al. (2011) did not find any $\mathrm{O}_{3}$ response at community level after 5 years of $\mathrm{O}_{3}$ exposure of a high

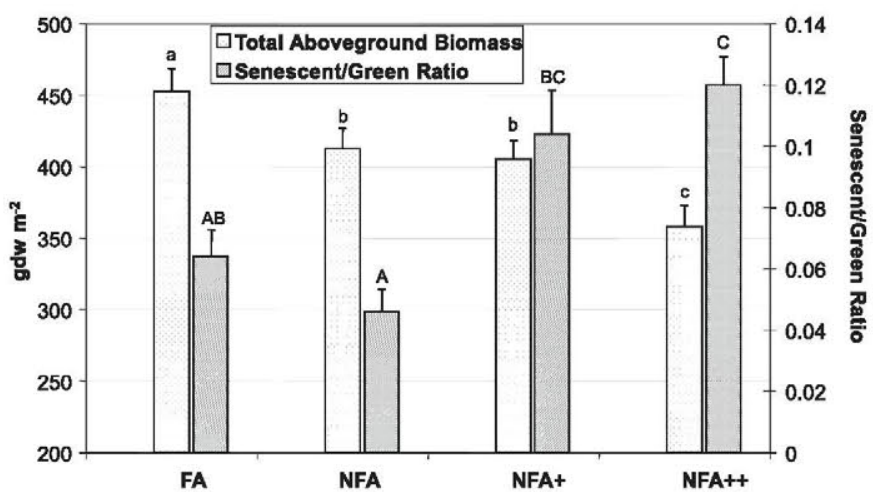

Fig. 4. Total aboveground biomass ( $\left(\mathrm{dw} \mathrm{m} \mathrm{m}^{-2}\right.$ ) and senescent/green biomass ratio for the different $\mathrm{O}_{3}$ treatments at the second harvest (mean across $\mathrm{N}$ treatments $\pm \mathrm{se}$ ). FA $=$ charcoal filtered air, NFA $=$ non filtered air, NFA $+=$ non filtered air supplemented with $20 \mathrm{nl} \mathrm{l}^{-1}$ of $\mathrm{O}_{3}$. NFA++ = non filtered air supplemented with $40 \mathrm{nl} \mathrm{l}^{-1}$ of $\mathrm{O}_{3}$. Different letters indicate significant differences among means. 


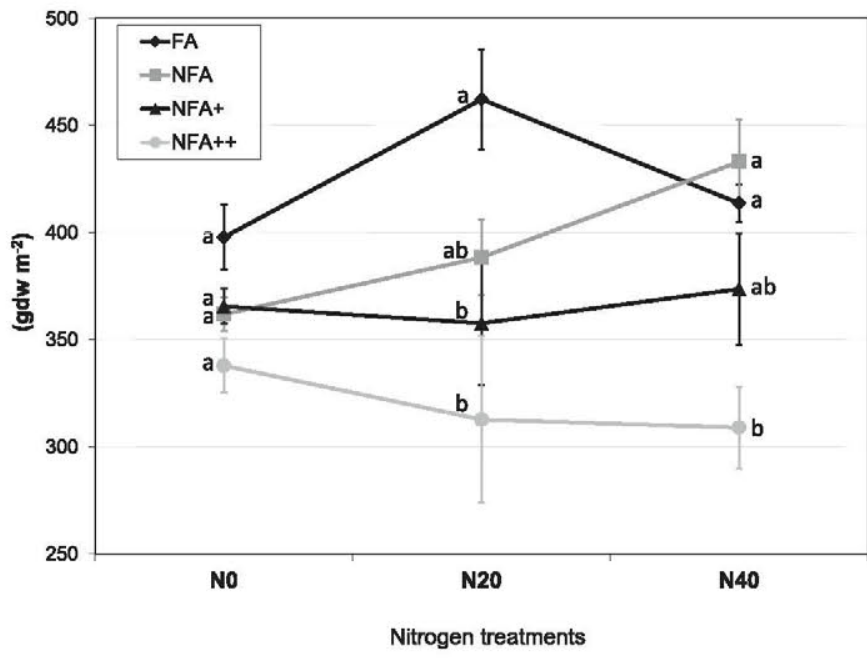

Fig. 5. Green biomass for the different $\mathrm{O}_{3}$ and $\mathrm{N}$ treatments at the second harvest (mean across $\mathrm{N}$ treatments $\pm \mathrm{se}$ ). $\mathrm{FA}=$ charcoal filtered air, NFA $=$ non filtered air, $\mathrm{NFA}+=$ non filtered air supplemented with $20 \mathrm{nl} \mathrm{l}^{-1}$ of $\mathrm{O}_{3}$, NFA $++=$ non filtered air supplemented with $40 \mathrm{nl} \mathrm{l}^{-1}$ of $\mathrm{O}_{3}$. NO = soil N background, $\mathrm{N} 20=20 \mathrm{~kg} \mathrm{~N} \mathrm{ha}^{-1}$; $\mathrm{N} 40=40 \mathrm{~kg} \mathrm{~N} \mathrm{ha}{ }^{-1}$. Different letters indicate significant differences among $\mathrm{O}_{3}$ treatments.

diverse alpine perennial grassland. Similarly, only small $\mathrm{O}_{3}$ effects on community composition were observed in calcareous grassland turfs after three growing seasons (Thwaites et al., 2006). The fact that annual communities regenerate each growing season from the seed bank with a fast growing rate when meteorological conditions are optimal, provides annual grasslands its characteristic state of non-maturity. In this sense, our results support the idea of Grime et al. (2000) that mature ecosystems exhibit greater inertia to stress and disturbance than newly established communities. Other sown model perennial communities have also shown quick and strong responses to $\mathrm{O}_{3}$ suggesting that high growing rates is among

Table 5

Mean values of the canopy gas exchange parameters expressed in terms of ground surface area $\left(\mu \mathrm{mol} \mathrm{CO} \mathrm{m}^{-2} \mathrm{~s}^{-1}\right.$ ) corresponding to the second harvest period for the different $\mathrm{O}_{3}$ treatments and phenological stages (mean \pm se). Values are averages across $\mathrm{N}$ treatments. FA = charcoal filtered air, NFA $=$ non filtered air, NFA $+=$ non filtered air supplemented with $20 \mathrm{nl} \mathrm{l}^{-1}$ of $\mathrm{O}_{3}$, NFA++ = non filtered air supplemented with $40 \mathrm{nl} \mathrm{I}^{-1}$ of $\mathrm{O}_{3} . \mathrm{NEE}=$ Ecosystem $\mathrm{CO}_{2}$ Exchange; $\mathrm{R}_{\mathrm{eco}}=$ Ecosystem Dark Respiration; GPP $=$ Gross Primary Production $\left(\mathrm{GPP}=\mathrm{NEE}-\mathrm{R}_{\mathrm{eco}}\right)$. DaE $=$ Days after Emergence. Different letters indicate significant differences among $\mathrm{O}_{3}$ treatments (across $\mathrm{N}$ treatments and phenological stages) and differences among phenological stages (across $\mathrm{N}$ and $\mathrm{O}_{3}$ treatments).

\begin{tabular}{|c|c|c|c|}
\hline & $\begin{array}{l}\mathrm{NEE}(\mu \mathrm{mol} \mathrm{CO} 2 \\
\left.\mathrm{m}^{-2} \mathrm{~s}^{-1}\right)\end{array}$ & $\begin{array}{l}R_{\mathrm{eco}}\left(\mu \mathrm{mol} \mathrm{CO} \mathrm{CO}_{2}\right. \\
\left.\mathrm{m}^{-2} \mathrm{~s}^{-1}\right)\end{array}$ & $\begin{array}{l}\mathrm{GPP}(\mu \mathrm{mol} \mathrm{CO} 2 \\
\left.\mathrm{m}^{-2} \mathrm{~s}^{-1}\right)\end{array}$ \\
\hline \multicolumn{4}{|l|}{ Experimental factors } \\
\hline Ozone & $<0.05$ & ns & $<0.01$ \\
\hline Nitrogen & ns & ns & ns \\
\hline Phenological stage & $<0.001$ & ns & $<0.001$ \\
\hline $\begin{array}{l}\mathrm{O}_{3} \times \text { phenological } \\
\text { stage }\end{array}$ & ns & $<0.1$ & ns \\
\hline \multicolumn{4}{|c|}{ Mean values per ozone treatment (across $N$ treatments and phenological stages) } \\
\hline FA & $17.31 \pm 1.60^{\mathrm{a}}$ & $-6.26 \pm 0.56$ & $8.77 \pm 1.63^{\mathrm{a}}$ \\
\hline NFA & $11.97 \pm 1.66^{\mathrm{b}}$ & $-7.82 \pm 0.65$ & $3.78 \pm 2.08^{\mathrm{ab}}$ \\
\hline $\mathrm{NFA}+$ & $13.50 \pm 1.10^{\mathrm{b}}$ & $-7.04 \pm 0.52$ & $6.22 \pm 1.66^{\mathrm{ab}}$ \\
\hline $\mathrm{NFA}++$ & $12.01 \pm 2.10^{\mathrm{ab}}$ & $-10.19 \pm 1.91$ & $1.76 \pm 3.14^{\mathrm{b}}$ \\
\hline \multicolumn{4}{|c|}{ Mean values per phenological stage (across $\mathrm{N}$ and $\mathrm{O}_{3}$ treatments) } \\
\hline $\begin{array}{l}\text { Vegetative stage } \\
\text { (47 DaE) }\end{array}$ & $16.4=1.14^{b}$ & $-7.33 \pm 0.84$ & $9.08 \pm 1.53^{a}$ \\
\hline $\begin{array}{l}\text { Reproductive stage } \\
\text { (62 DaE) }\end{array}$ & $25.81 \pm 1.56^{c}$ & $-8.05 \pm 0.86$ & $16.3 \pm 2.67^{a}$ \\
\hline $\begin{array}{l}\text { Senescence stage } \\
\text { (91 DaE) }\end{array}$ & $9.20 \pm 0.70^{\mathrm{a}}$ & $-7.82 \pm 0.48$ & $1.28 \pm 1.12^{\mathrm{b}}$ \\
\hline
\end{tabular}

the main plant trait related to $\mathrm{O}_{3}$-sensitivity (see review in Bassin et al., 2007).

In addition to reductions in green and total aboveground biomass, $\mathrm{O}_{3}$ significantly increased the senescent biomass of the annual pasture. The $\mathrm{O}_{3}$-induction of premature senescence has been frequently observed in different vegetation types (Ashmore, 2005) and was also reported in previous experiments performed with annual single species (Bermejo et al., 2003; Sanz et al., 2007). Premature senescence together with reduction of aboveground biomass would imply lower plant resources for flower and seed development determining annual community viability. In fact, the $\mathrm{O}_{3}$-induced reduction of the reproductive capacity of some annual legumes has been demonstrated in experiments with individual species (Gimeno et al., 2004b). Results of the $\mathrm{O}_{3}$ effects on biomass, flower and seed production of the individual species forming this annual community are presented elsewhere (Calvete-Sogo et al., 2013).

The $\mathrm{O}_{3}$ effects on pasture biomass were related to the observed response of gas exchange rates since reductions of NEE up to $28 \%$ were recorded. Similar results were observed when NEE was expressed based on dry biomass or on ground surface area. Thus $\mathrm{O}_{3}$ effects on NEE at canopy level were partially explained by the $\mathrm{O}_{3}$ induced reduction in biomass, but photosynthetic and/or respiration rates of the pasture were also affected. Indeed, $\mathrm{O}_{3}$ increased dark respiration when calculated on biomass weight basis, but effects on photosynthetic rates cannot be disregarded $\left(\mathrm{O}_{3}\right.$ effects on photosynthesis at leaf level are presented elsewhere: Calvete-Sogo et al., 2013). Dark $\mathrm{CO}_{2}$ fluxes include aboveground plant respiration, plant root respiration and soil microbial respiration, representing a combination of plant and soil processes. Since aboveground biomass was responsible of $70 \%$ of the observed dark respiration at the late phenological stage, effects on plant metabolism could mask the effects on soil processes. A test with a limited amount of replicated measurements showed that $\mathrm{O}_{3}$ strongly increased bare soil dark respiration $\left(-3.9 \mu \mathrm{mol} \mathrm{CO} \mathrm{Cm}^{-2} \mathrm{~s}^{-1}\right.$ in NFA + compared to $-1.78 \mu \mathrm{mol} \mathrm{CO} \mathrm{m}^{-2} \mathrm{~s}^{-1}$ in $\mathrm{FA}$; data not shown) suggesting that $\mathrm{O}_{3}$ could be affecting both plant and soil processes. Further research is needed to clarify possible $\mathrm{O}_{3}$ effects on soil metabolism. The combined effects of reducing NEE and increasing dark respiration resulted in a significant $\mathrm{O}_{3}$-induced reduction of GPP. Recent works indicate that $\mathrm{O}_{3}$ can reduce $\mathrm{C}$ sequestration in tree living biomass (Harmens and Mills, 2012). However, quantifying the $C$ budget of grassland systems is still challenging and further investigation is needed to quantify $\mathrm{O}_{3}$ effects on $\mathrm{C}$ sequestration in annual grasslands.

Increasing $\mathrm{N}$ availability slightly affected annual pasture development. The low $\mathrm{N}$ doses used in this experiment, selected to reproduce the potential range of atmospheric $\mathrm{N}$ deposition in this area, increased soil mineral $\mathrm{N}$ content but these doses were not enough to significantly affect the yield or gas exchange rates of the annual pasture. The background soil $\mathrm{N}$ content of the soil $(10 \mathrm{mg}$ $\mathrm{N}_{\min } \mathrm{kg}^{-1}$ i.e. $33 \mathrm{~kg} \mathrm{~N} \mathrm{~N}_{\min } \mathrm{ha}^{-1}$ ) seemed to be enough to cover pasture $\mathrm{N}$ nutritional demand, explaining the lack of response to low $\mathrm{N}$ additions. Natural annual pastures usually grow in low fertility soils (Vázquez-De-Aldana et al., 2008) and a soil N content representing one tenth of the background soil $\mathrm{N}$ content of our experiment has been reported in natural annual pastures in Portugal (Hussain et al., 2009). Other nutrients, such as phosphorus, could be limiting plant development in this ecosystem type.

Despite the low responsiveness to $\mathrm{N}$, a significant interactive response between $\mathrm{N}$ and $\mathrm{O}_{3}$ was detected in green and total aboveground biomass production. On the one hand, $\mathrm{O}_{3}$ reduced the fertilization effect of higher $\mathrm{N}$ availability since yield responses to $\mathrm{N}$ addition were positive only under low $\mathrm{O}_{3}$ levels. This effect was not 

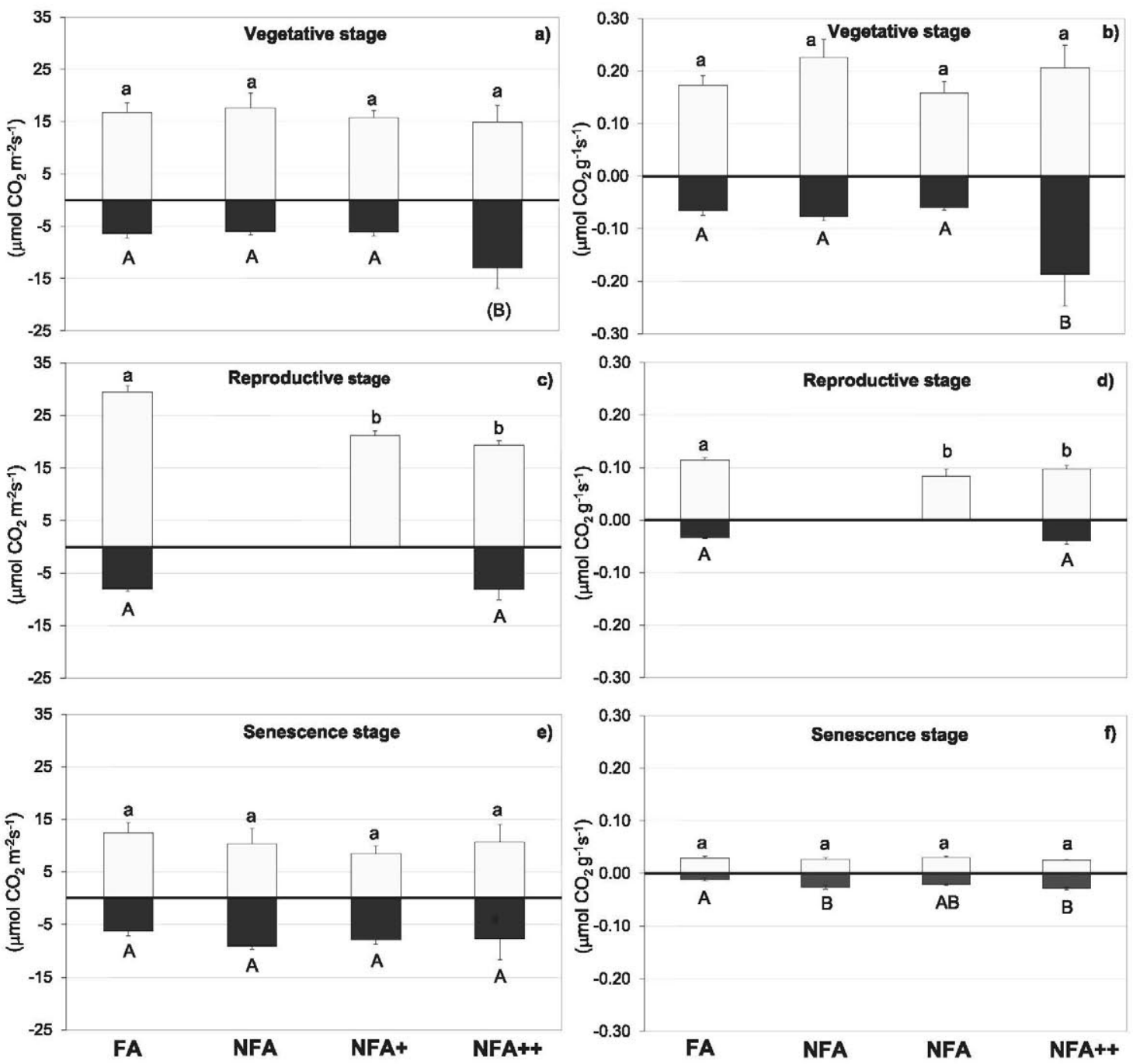

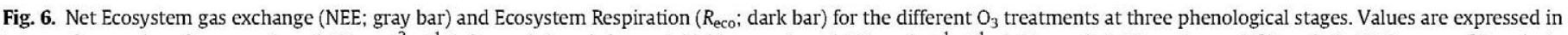

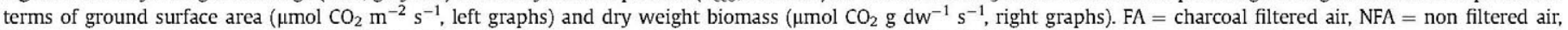

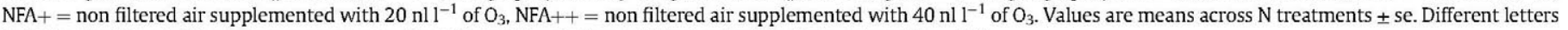
indicate significant differences among means for NEE and $R_{\text {eco }}$; letters within brackets indicate a trend $(p<0.1)$.

explained by a reduction of root growth or root/aboveground biomass ratio, suggesting that $\mathrm{O}_{3}$ could be affecting plant metabolism related to nitrogen. On the other hand, $\mathrm{N}$ seemed to counterbalance $\mathrm{O}_{3}$ yield reductions when pollutant levels were moderate, but this compensation was not observed in the high $\mathrm{O}_{3}$ exposure treatment. A similar positive influence of $\mathrm{N}$ on $\mathrm{O}_{3}$ effects on yield and quality parameters has been already detected when annual plants have been tested individually (Sanz et al., 2005, 2007, 2011). Other authors have highlighted the importance of nutrient availability in modifying $\mathrm{O}_{3}$ responses of semi-natural vegetation (Bassin et al., 2007) but these interactions need further characterization in different vegetation types.

Ozone exposure-response functions were built based on the results obtained in this experiment using the relative yield loss of green and total aboveground biomass in the second harvest as the response parameter, and the accumulated $\mathrm{O}_{3}$ exposure from the start of the $\mathrm{O}_{3}$ exposure until the harvest (from 47 till 85 DaE, i.e. 38 days). Considering a 10\% yield loss, the exposure-based critical level for annual communities would be $3545 \mathrm{nl} \mathrm{l}^{-1} \mathrm{~h}$ and $4249 \mathrm{nl} \mathrm{l}^{-1} \mathrm{~h}$ for green and total aboveground biomass respectively $\left(y=-0.0021 x+97.44, R^{2}=0.94, p<0.05\right.$ for green biomass and $y=-0.0016 x+96.80, R^{2}=0.84, p<0.05$ for total aboveground biomass). These values are slightly above the critical level of $3000 \mathrm{nl} \mathrm{l}^{-1} \mathrm{~h}$ currently proposed for the protection of grasslands dominated by annuals species (CLRTAP, 2010). In any case, $\mathrm{O}_{3}$ concentrations in the Iberian Peninsula where annual pastures grow frequently exceed these values (Fernández-Fernández et al., 2011) Also, critical levels are above the long-term objective of $3000 \mathrm{nl} \mathrm{l}^{-1} \mathrm{~h}$ established by the EU Air Quality Directive for plant protection, but below the current target of $9000 \mathrm{nl} \mathrm{l}^{-1} \mathrm{~h}$ defined by the Air Quality Directive to be met since 2010.

\section{Conclusions}

Ozone exposure induced visible injury and reduced the yield and gross primary production of a model annual community. Even ambient $\mathrm{O}_{3}$ levels were enough to decrease aboveground biomass and NEE. Small increments of soil $\mathrm{N}$ availability slightly altered pasture growth but a significant interactive effect with $\mathrm{O}_{3}$ exposure was detected. While $\mathrm{O}_{3}$ limited the fertilization effect of higher soil 
$\mathrm{N}$ availability, higher $\mathrm{N}$ could compensate $\mathrm{O}_{3}$ effects on yield only when concentrations were moderate, but not under high $\mathrm{O}_{3}$ levels. The response of the annual community was related to the cumulative $\mathrm{O}_{3}$ exposure during the experiment suggesting an $\mathrm{O}_{3}$ critical level of $4000 \mathrm{nl} \mathrm{l}^{-1} \mathrm{~h}$ to protect this vegetation type against a $10 \%$ yield loss. Since $\mathrm{O}_{3}$ concentrations in the Mediterranean area frequently exceed that level, $\mathrm{O}_{3}$ must be considered as a stress factor for annual pastures that can affect the yield, structure and composition of these ecosystems.

\section{Acknowledgments}

This research was funded by the Spanish projects MONTES (CONSOLIDER-INGENIO CSD2008-00040), AGRISOST (S2009AGR1630, Comunidad de Madrid), EDEN (CGL2009-13188-C03-02) and the EU-FP7-ENV-2011 ECLAIRE project. The OTC field site at "La Higueruela Research Farm" was possible thanks to an agreement between CIEMAT and Museo de Ciencias Naturales/CSIC. Appreciative acknowledgment is extended to Carlos Lacasta Dutoit, José María Gómez Camacho and La Higueruela/CSIC research farm staff for their valuable suggestions in the experimental design and their technical support in the field work.

\section{Appendix}

Table A.1Edaphic and physico-chemical characteristics of Ap horizon.

\begin{tabular}{lll}
\hline Edaphic characteristics & Organic matter by oxidation (\%) & 1.26 \\
& \% Clay & 11.4 \\
& \% Silt & 24.0 \\
& \% Sand & 64.6 \\
Physic-chemical characteristics & $\mathrm{pH}$ & 6.9 \\
& Olsen P (ppm) & 39 \\
& Changes N (ppm) & 62 \\
& Changes K (ppm) & 244 \\
& Changes Ca (ppm) & 1780 \\
& Changes K (ppm) & 160 \\
N mineral Content & $\mathrm{NO}_{3}(\mathrm{mg} \mathrm{N} / \mathrm{kg}$ soil) & 17.26 \\
& $\mathrm{NH}_{4}^{+}(\mathrm{mg} \mathrm{N} / \mathrm{kg}$ soil) & 0.16 \\
\hline
\end{tabular}

\section{Assessing the chamber effect: AA Plots vs. NFA OTCS}

AOT40 values in NFA chambers were slightly lower (average difference of $25 \%$ ) than in ambient air (Table 3 ). In regards to meteorological conditions, an increment of 1.6 of temperature and a decrease of $148 \mu \mathrm{mol} \mathrm{m} \mathrm{m}^{-2} \mathrm{~s}^{-1}$ in PAR were recorded inside the OTC compared to AA plots since plant emergence till the second harvest. The other meteorological parameters did not present important differences to be highlighted (differences in soil temperature $<1{ }^{\circ} \mathrm{C}$, in SWC $<0.2 \mathrm{~m}^{-3}$ and in air relative humidity $<4 \%$ ). The growing pattern and canopy gas exchange values were compared between pasture growing in NFA chambers and in AA plots in order to control the chamber effect (Fig. A.1). Although no differences were recorded on species germination and distribution between AA and NFA plots, significant differences $(p<0.05)$ in total aboveground biomass were detected at the early stage of pasture development (Vegetative Stage, $46 \mathrm{DaE}$ ), when biomass inside the OTCs was almost $50 \%$ higher than in AA plots (mean value across $\mathrm{N}$ treatments; Fig. A.1). Similar results were found for green biomass. The same pattern was found in NEE values (Fig. A.1b), although these differences represented only a statistical trend $(p<0.1)$. This early delay in pasture development found in AA plots disappeared during the spring peak growth and no significant differences were recorded in the following biomass harvests or gas exchange assessments.
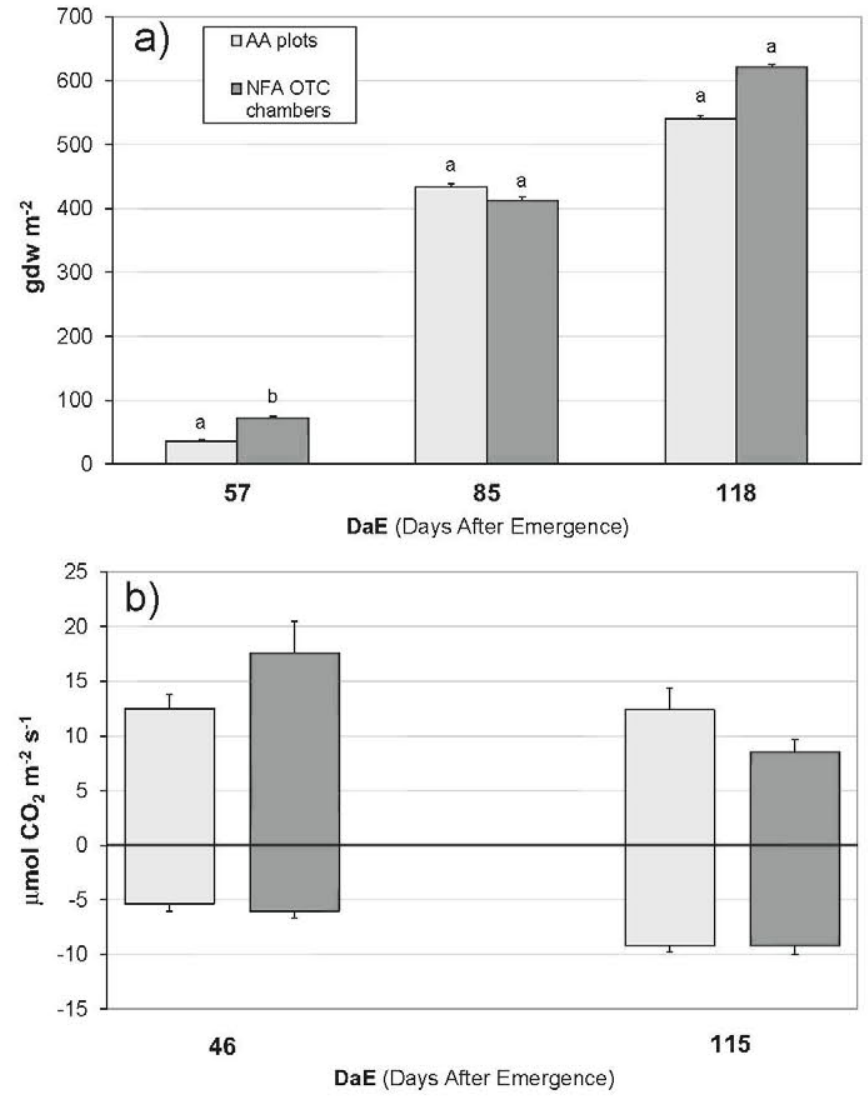

Fig A.1. Total aboveground biomass (a) and gas exchange (NEE and $R_{\text {eco }}$ ) (b) for ambient plots $(A A)$ and non-filtered air chambers (NFA) to test the chamber effect. Different letters indicate significant differences between means (mean $\pm \mathrm{se}$ ).

\section{Appendix A. Supplementary data}

Supplementary data related to this article can be found at http:// dx.doi.org/10.1016/j.atmosenv.2014.05.073.

\section{References}

Ashmore, M.R., 2005. Assessing the future global impacts of ozone on vegetation. Plant Cell. Environ. 28, 949-964.

Àvila, A., Rodà, F., 2012. Changes in atmospheric deposition and streamwater chemistry over 25 years in undisturbed catchments in a Mediterranean mountain environment. Sci. Total Environ. 434, 18-27.

Bassin, S., Volk, M., Fuhrer, J., 2007. Factors affecting the ozone sensitivity of temperate European grasslands: an overview. Environ. Pollut. 146, 678-691.

Bermejo, V., Gimeno, B.S., Sanz, J., De la Torre, D., Gil, J.M., 2003. Assessment of the ozone sensitivity of 22 native plant species from Mediterranean annual pastures based on visible injury. Atmos. Environ. 37, 4667-4677.

Bermejo, V., Gonzalez-Fernandez, I., Calvo, E., Alonso, R., 2011. Ozone effects on crops in Mediterranean Europe. In: Mills, G., Harmens, H. (Eds.), Ozone Pollution: a Hidden Threat to Food Security. ICP Vegetation Programme Coordination Centre, UNECE-CLRTAP WGE, p. 112.

Bytnerowicz, A., 2002. Physiological/ecological interactions between ozone and nitrogen deposition in forest ecosystems. Phyt. Rei Bot. 42, 13-28.

Cape, J.N., 2008. Surface ozone concentrations and ecosystem health: past trends and a guide to future projections. Sci. Total Environ. 400, 257-269.

Calvete-Sogo, H., Bermejo, V., Sánchez, L., Muntifering, R., Sanz, J., Elvira, S., González-Fernández, I., Vallejo, A., Alonso, R., 2013. Ozone and nitrogen effects on the annual understory vegetation of open holm oak forest. IUFRO meeting (Vegetation Response Climate Change and Air Pollution - Unifying Evidence and Research across Northern and Southern Hemisphere), Ilhéus, Bahia, Brazil, September 1-6.

CLRTAP, 2010. Manual on Methodologies and Criteria for Modelling and Mapping Critical Loads and Levels, and Air Pollution Effects, Trends and Risks. Chapter 3: Mapping Critical Levels for Vegetation. Convention on Long-Range Transboundary Air Pollution. http://www.icpmappinmg.org/.

Cristofanelli, P., Bonasoni, P., 2009. Background ozone in the southern Europe and Mediterranean area: influence of the transport processes. Environ. Pollut. 157, $1399-1406$ 
Dupre, C., Stevens, C.J., Ranke, T., et al., 2010. Changes in species richness and composition in European acidic grasslands over the past 70 years: the contribution of cumulative atmospheric nitrogen deposition. Glob. Change Biol. 16, 344-357.

EEA, 2011. Air Quality in Europe - 2011 Report Technical Report No. 12/2011. European Environment Agency, Copenhagen.

Emmett, B.A., 2007. Nitrogen saturation of terrestrial ecosystems: some recent findings and their implications for our conceptual framework. Water Air Soil. Pollut. Focus 7, 99-109.

Fernández-Fernández, M.I., Gallego, M.C., García, J.A., Acero, F.J., 2011. A study of surface ozone variability over the Iberian Peninsula during the last fifty years. Atmos. Environ. 45, 1946-1959.

Ferretti, M., Bussotti, F., Calatayud, V., Schaub, M., Kräuchi, N., Petriccione, B., Sanchez-Peña, G., Sanz, M.J., Ulrichf, E., 2007. Ozone and forests in South-Western Europe. Environ. Pollut. 145, 617-619.

García, R.L., Norman, J.M., Mcdermitt, D.K., 1990. Measurement of canopy gas exchange using an open chamber system. Remote Sens. Rev. 5 (1), 141-162.

García-Gómez, H., Garrido, J.L, Vivanco, M.G., Lassaletta, L., Rabago, I., Àvila, A. Tsyro, S., Sánchez, G., González Ortiz, A., González-Fernández, I., Alonso, R., 2014. Nitrogen deposition in Spain: modeled patterns and threatened habitats within the Natura 2000 Network. Sci. Total Environ. 485-486, 450-460.

Gimeno, B.S., Bermejo, V., Sanz, J., De la Torre, D., Elvira, S., 2004a. Growth response to ozone of annual species from Mediterranean pastures. Environ. Pollut. 132 297-306.

Gimeno, B.S., Bermejo, V., Sanz, J., De la Torre, D., Gil, J.M., 2004b. Assessment of the effects of ozone exposure and plant competition on the reproductive ability of three therophytic clover species from Iberian pastures. Atmos. Environ. 38, 2295-2303.

Grime, J.P., Brown, V.K., Thompson, K., et al., 2000. The response of two contrasting limestone grasslands to simulated climate change. Science 289, 762-765.

Harmens, H., Mills, G., 2012. Ozone Pollution: Impacts on Carbon Sequestration in Europe. Programme Coordination Centre for the ICP Vegetation. Centre for Ecology and Hydrology, Bangor, UK, ISBN 978-1-906698-31-7.

Hayes, F., Jones, M.L.M., Mills, G., Ashmore, M., 2007. Meta-analysis of the relative sensitivity of semi-natural vegetation species to ozone. Environ. Pollut. 146 $754-762$.

Heck, W.W., Taylor, O.C., Adams, R., Bingham, G., Miller, H., Preston, E., Weinstein, L., 1982. Assessment of crop loss from ozone. J. Air Pollut. Control Assoc. 32, 353-361.

Hussain, Z., Kemp, P.D., Horne, D.J., Jaya, I.K.D., 2009. Pasture production under densely planted young willow and poplar in a silvopastoral system. Agrofor Syst. 76, 351-362.

Millán, M.M., Mantilla, E., Salvador, R., et al., 2000. Ozone cycles in the western Mediterranean basin: interpretation of monitoring data in complex coastal terrain. J. Appl. Meteorol. 39, 487-508.
Montoya, J.M., Meson, M., Ruiz, J., 1988. Una dehesa testigo, La dehesa de Moncalvillo, Serie Técnica num 5. Ministerio de Agricultura Pesca y Alimentación, ICONA, p. 134.

Ochoa-Hueso, R., Allen, E.B., Branquinho, C., et al., 2011. Nitrogen deposition effects on Mediterranean-type ecosystems: an ecological assessment. Environ. Pollut. $159,2265-2279$

Olea, L., San-Miguel-Ayanz, A., 2006. The Spanish dehesa. A traditional Mediterranean silvopastoral system linking production and nature conservation. In: Lloveras, J., González-Rodríguez, A., Vázquez-Yañez, O., Piñeiro, J., Santamaría, O., Olea, L., Poblaciones, M.J. (Eds.), Sustainable Grassland Productivity: Proceedings of the 21st General Meeting of the European Grassland Federation, pp. 1-15.

Sanz, J., Muntifering, R.B., Bermejo, V., Gimeno, Bs, Elvira, S., 2005. Ozone and increased nitrogen supply effects on the yield and nutritive quality of Trifolium subterraneum. Atmos. Environ. 39, 5899-5907.

Sanz, J., Bermejo, V., Gimeno, B.S., Elvira, S., Alonso, R., 2007. Ozone sensitivity of the Mediterranean terophyte Trifolium striatum is modulated by soil nitrogen content. Atmos. Environ. 41, 8952-8962.

Sanz, J., Bermejo, V., Muntifering, R.B., González-Fernández, I., Gimeno, B.S. Elvira, S., Alonso, R., 2011. Plant phenology, growth and nutritive quality of Briza maxima: responses induced by enhanced ozone atmospheric levels and nitrogen enrichment. Environ. Pollut. 159, 423-430.

Stampfli, A., Fuhrer, J., 2010. Spatial heterogeneity confounded ozone-exposure experiment in semi-natural grassland. Oecologia 162, 515-522.

Stevens, C.J., Dise, N.B., Mountford, J.O., Gowing, D.J., 2004. Impact of nitrogen deposition on the species richness of grasslands. Science 303, 1876-1879.

Sutton, M.A., Howard, C.M., Erisman, J.W., Billen, G., Bleeker, A., Grennfelt, P., Grinsven, H.V., Grizzetti, B. (Eds.), 2011. The European Nitrogen Assessment. Cambridge Univ. Press.. Available at: http://go.nature.com/5n9lsq.

Thwaites, R.H., Ashmore, M.R., Morton, A.J., Pakeman, R.J., 2006. The effects of tropospheric ozone on the species dynamics of calcareous grassland. Environ. Pollut. 144, 500-509.

Vázquez-De-Aldana, B.R., García-Ciudad, A., García-Criado, B., 2008. Interannual varjations of above-ground biomass and nutritional quality of Mediterranean grasslands in Western Spain over a 20-year period. Aust. J. Agric. Res. 59, 769-779.

Volk, M., Bungener, P., Contat, F., Montani, M., Fuhrer, J., 2006. Grassland yield declined by a quarter in 5 years of free-air ozone fumigation. Glob. Change Biol $12,74-83$.

Volk, M., Obrist, D., Novak, K., Giger, R., Bassin, S., Fuhrer, J., 2011. Subalpine grassland carbon dioxide fluxes indicate substantial carbon losses under increased nitrogen deposition, but not at elevated ozone concentration. Glob. Change Biol. 17, 366-376.

Wyness, K., Mills, G., Jones, L., Barnes, Jd, Jones, D.L., 2011. Enhanced nitrogen deposition exacerbates the negative effect of increasing background ozone in Dactylis glomerata, but not Ranunculus acris. Environ. Pollut. 159, 2493-2499. 